\title{
PENGEMBANGAN COURSEWARE DIGITAL LEARNING UNTUK MENINGKATKAN KETERAMPILAN GENERIK SAINS DAN PENGUASAAN KONSEP SISWA PADA TOPIK HIDROKARBON
}

\author{
Ita Inayah
}

itainayah@gmail.com

\begin{abstract}
Penelitian ini bertujuan untuk mengembangkan courseware digital learning yang dapat meningkatkan kemampuan generik sains dan penguasaan konsep siswa pada topik hidrokarbon. Penelitian ini menggunakan metode Research and Development $(R \& D)$ )yang terbatas hingga tahap studi pendahuluan. Studi pendahuluan tersebut meliputi studi literatur dan pengembangan produk awal. Pada tahap studi literatur dilakukan kajian terhadap berbagai courseware digital learning pada topik hidrokarbon yang telah tersedia. Sementara itu, berdasarkan hasil studi literatur, pada tahap pengembangan produk awal, dilakukan analisis, desain, produksi, validasi dan revisi produk. Penelitian ini menghasilkan suatucourseware materi hidrokarbon yang didesain untuk memperbaiki kekurangan-kekurangan dari courseware yang sudah ada sebelumnya khususnya pada topik hidrokarbon dalam sisi keinteraktifan. Sejumlah bentuk interaksi dapat dimunculkan melalui courseware seperti tutorial dan drill\&practise. Siswa dimungkinkan untuk memberikan respon, menerima umpan balik, menerima koreksi, mempunyai kesempatan untuk perbaikan dan memperoleh penguatan yang memadai.
\end{abstract}

Keywords:Courseware digital learning, Research and Development (R\&D), Keterampilan Generik Sains, Penguasaan Konsep, Hidrokarbon

\section{PENDAHULUAN}

Perkembangan teknologi dan informasi saat ini sudah berkembang sangat cepat dan hal ini berpengaruh terhadap pribadi, aktivitas, kehidupan dan cara berpikir seseorang. Pemanfaatan dari perkembangan teknologi dan informasi sudah bisa dirasakan dalam berbagai bidang salah satunya dalam bidang pendidikan. Pemanfaatan teknologi dan informasi dalam bidang pendidikan khususnya dalam pembelajaran perlu dikenalkan kepada guru dan siswa agar mereka memiliki bekal pengetahuan dan pengalaman untuk menerapkan dan menggunakannya dalam kegiatan belajar-mengajar. Dalam proses pembelajaran saat ini banyak dikembangkan media-media pembelajaran berbasis komputer, salah satunya pembuatan dan pengembangan software dalam media pembelajaran.

Perkembangan teknologi dan informasi memungkinkan dihasilkannya berbagai multimedia interaktif dalam pembelajaran. Pemanfaatan penggunaan multimedia interaktif sangat membantu dalam mata pelajaran sains khususnya kimia. Untuk mata pelajaran kimia, siswa menganggap bahwa mata pelajaran ini sulit dipahami terutama pada konsep-konsep abstrak. Menurut penelitian Liliasari (1997), rendahnya penguasaan konsep kimia disebabkan oleh pola pikir rasional yang rendah pada pembentukan sistem konseptual kimia.

Hal ini dikarenakan pembelajaran kimia sebagian besar dilakukan dengan metode ceramah dan kegiatannya lebih berpusat pada guru, sehingga siswa cenderung hanya mendengarkan penjelasan guru dan mencatat hal-hal yang dianggap penting. Tidak sedikit siswa yang sulit mengikuti cara guru menjelaskan suatu konsep kimia, akibatnya siswa tidak memahami konsep yang sebenarnya. Siswa tidak memiliki kemampuan untuk bertanya, mengakibatkan semakin sulit untuk memahami konsep yang diberikan oleh guru. Jadi belajar kimia memerlukan 
kemampuan untuk dapat membangun konsep, agar bisa ditelaah untuk memperoleh pemahaman yang lebih lanjut dan konsep-konsep inilah yang diuji keterapannya (Liliasari, 2005).

Pengembangan multimedia interaktif yang berorientasi pada pemodelan konsep yang bersifat abstrak perlu dilakukan agar materi tersebut dapat lebih mudah dipelajari, sekaligus untuk mengembangkan keteramplan berpikir salah satunya keterampilan berpikir generik. Kartimi (2003) dengan penelitiannya pengembangan model pembelajaran interaktif berbasis komputer untuk bahan kajian partikel-partikel materi sebagai wahana pendidikan siswa SLTP, menemukan bahwa model pembelajaran yang menggunakan komputer dapat meningkatkan keterampilan berpikir kreatif siswa dan mampu menyajikan materi-materi yang biasanya dilakukan oleh guru sehingga guru dapat lebih memperhatikan siswa yang lambat dalam penerimaan pembelajaran. Kristi (2008) Selain penguasaan konsep, pembelajaran berbasis multimedia interaktif juga dapat meningkatkan keterampilan generik sains dan berpikir kritis siswa. Tapilouw (2007) Pengembangan dan implementasi multimedia interaktif menunjukkan dampak positif bagi peningkatan kualitas pembelajaran sains.

Untuk kepentingan penelitian ini salah satu materi kimia yang dipilih adalah hidrokarbon. Materi hidrokarbon meliputi alkana, alkena, alkuna dan keisomeran. Hidrokarbon merupakan materi dengan konsep abstrak sehingga memerlukan visualisasi agar siswa lebih mudah memahaminya. Teknologi komputer adalah sebuah penemuan yang memungkinkan menghadirkan beberapa atau semua bentuk interaksi sehingga pembelajaran akan lebih optimal. Penelitian ini menghasilkan sebuah courseware materi hidrokarbon yang mudah dipelajari. Sejumlah bentuk interaksi dapat dimunculkan melalui courseware seperti penyajian simulasi, latihan dan tutorial. Siswa dimungkinkan untuk memberikan respon, menerima umpan balik, menerima koreksi, mempunyai kesempatan untuk perbaikan dan memperoleh penguatan yang memadai. Sehingga pembelajaran berbasis multimedia interaktif dapat mengarahkan proses bagaimana siswa belajar agar pembelajaran yang dihasilkan lebih bermakna dan berkesan (Harun dan Tasir, 2003).

\section{METODE}

Penelitian ini menggunakan metodepenelitian research and development ( $R \& D$ ) yang terbataspada tahap studi pendahulan.Pada studi pendahuluan tersebut dilakukan studi literatur dan pengembangan produk awal. Pada studi literatur yang dilakukan adalah melakukan kajian terhadap berbagai courseware pada topik hidrokarbon yang telah tersedia. Sumber data yang digunakan adalah beberapa tesis dan skripsi di UPI yang diterbitkan antara tahun 2005-2010 yang membahas tentang penerapan multimedia interaktif pada topik hidrokarbon.

Pada tahap pengembangan produk awal, ada beberapa langkah yang dilkukan yaitu:

1. Tahap Analisis

Pada tahapan ini peneliti melakukan analisis konsep hidrokarbon, menentukan sasaran pengguna courseware, apa saja yang akan dan harus dipelajari oleh peserta didik, pengetahuanpengetahuan sebagai prasyarat yang harus dimiliki oleh peserta didik, dan berapa lama durasi efektif yang diperlukan untuk menggunakan courseware dalam proses pembelajaran.

2. Tahap Desain

Pada tahapan ini ditetapkan tujuan yang ingin dicapai dari courseware pembelajaran yang akan dibuat, model pembelajaran yang akan diterapkan dan penetapan isi materi yang akan dijadikan inti pembelajaran dalam courseware. Selain itu pada tahap ini peneliti mulai merancang storyboard yang nantinya akan dijadikan rujukan pada tahap produksi courseware.

3. Tahap produksi

Pada tahapan ini courseware pembelajaran mulai dikembangkan sesuai dengan yang sudah ditetapkan sebelumnya dalam tahapan desain. Pada tahapan ini yang diperhatikan adalah penerapan sistem yang akan digunakan dan prinsip dari courseware yaitu kesesuaian, kemudahan, kemenarikan dan kemanfaatan.

4. Validasi Produk

Pada tahapan ini courseware yang telah dibuat diuji kelayakannya oleh dosen ahli dalam bidang media pembelajaran dan dosen ahli dalam bidang materi kimia organik

5. Revisi Produk

Pada tahapan ini, courseware yang telah dibuat direvisi berdasarkan hasil dari pertimbangan dosen ahli dalam bidang media pembelajaran dan dosen ahli dalam bidang kimia organik 


\section{HASIL DAN PEMBAHASAN}

1. Karakteristik multimedia interaktif pada topik hidrokarbon yang pernah ada.

Berdasarkan hasil analisis kajian studi literature terhadap tesis dan skripsi yang diterbitkan antara tahun 2005-2010 yang berfokus pada penerapan multimedia interaktif untuk topik hidrokarbon, didapatkan hasil sebagai berikut:

Menurut Thorn (dalam Karyadinata, 2006) terdapat enam kriteria untuk menilai keinteraktifan suatu multimedia pembelajaran, yaitu 1) Kemudahan navigasi, sebuah program harus dirancang sesederhana mungkin sehingga pembelajar tidak perlu belajar komputer terlebih dahulu, 2) Kandungan kognisi, 3) Pengetahuan dan presentasi informasi, kriteria kedua dan ketiga adalah untuk menilai isi dari program itu sendiri, apakah program telah memenuhi kebutuhan pembelajar atau belum, 4) Integrasi media, suatu media harus mengintegrasikan aspek dan keterampilan yang harus dipelajari, 5) Estetika, suatu program harus mempunyai tampilan artistik untuk menarik minat pembelajar, 6) Fungsi secara keseluruhan, program yang dikembangkan harus memberikan pembelajaran yang diinginkan oleh pembelajar, sehingga pada waktu seseorang selesai menjalankan sebuah program dia akan merasa telah belajar sesuatu.

Dari data yang ada, dapat disimpulkan bahwamedia yang dihasilkan antara tahun 20052010 khususnya pada topik hidrokarbon hanya sebatas multimedia, kurang memperlihatkan keinteraktifan dari suatu multimedia. Ini dapat diketahui dari kegiatan siswa yang hanya membaca teks yang ditampilkan di layar dan mengklik tombol yang telah disediakan apabila ia ingin melihat atau membaca konsep-konsep lainnya. Siswa tidak dilibatkan dalam proses penemuan suatu konsep. Tampilan keluaran yang terdapat di layar komputer terlalu banyak menampilkan teks, sehingga seperti memindahkan bahan bacaan yang terdapat dalam buku ke dalam bentuk lain berupa tampilan komputer.

2. Karakteristik courseware digital learing

Sebelum membahas karakteristik dari courseware, peneliti terlebih dahulu memaparkan data mengenai kelebihan dan kekurangan dari courseware. Kelebihan dari couseware

1. Sesuai dengan tujuan pembuatannya, courseware ini dapat melatih siswa dalam mengembangkan kemampuan generik sains siswa pada indikator kerangka taat asas, inferensi logika, dan bahasa simbolik.

Contoh indikator kerangka taat asas Contoh indikator inferensi logika
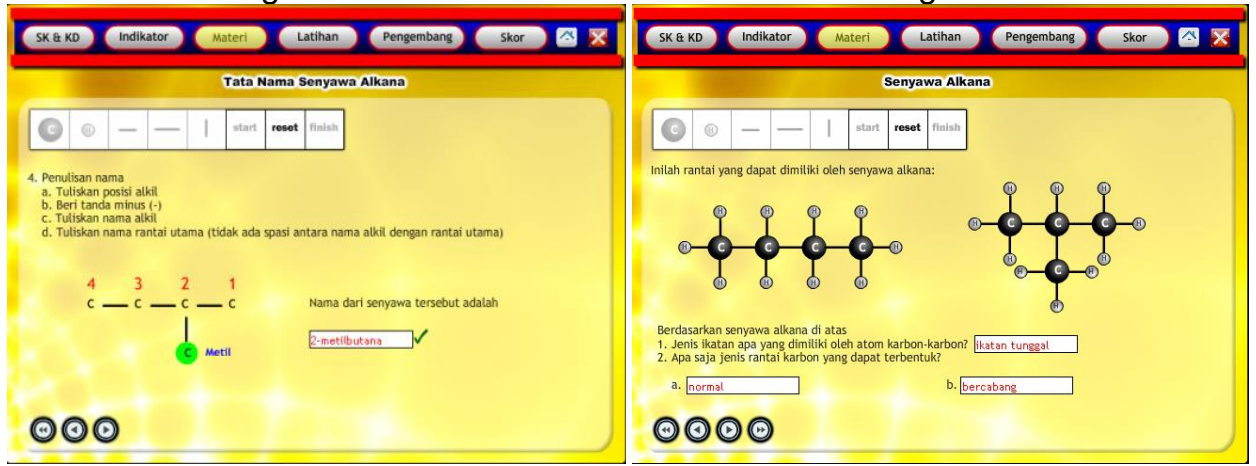

Contoh indikator bahasa simbolik

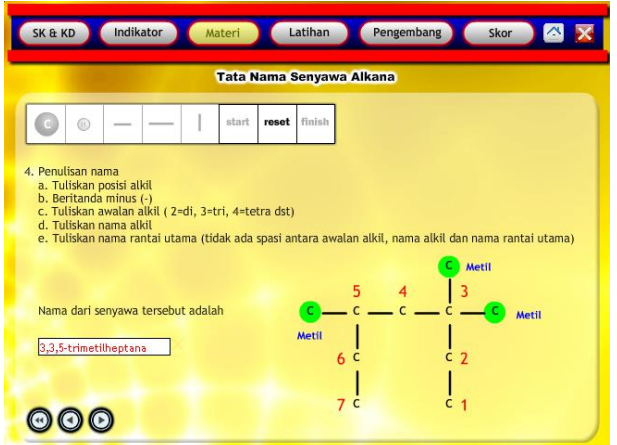

2. Konsep-konsep yang terdapat pada courseware ditampilkan secara bertahap berdasarkan hierarki konsep. Misal siswa tidak akan dapat mempelajari alkena sebelum siswa mempelajari alkana dan siswa tidak dapat mengerjakan latihan alkana sebelum siswa mempelajari materi alkana 


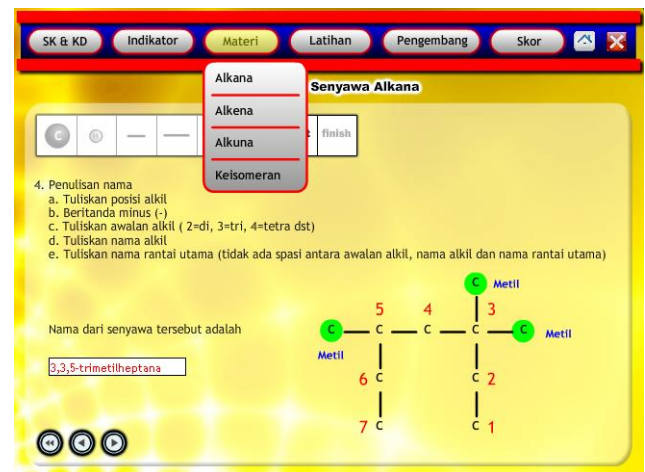

3. Konten materi dan konten latihan yang terdapat pada courseware dilengkapi dengan password. Siswa dapat mengetahui password setelah siswa menyelesaikan satu konten materi ataupun mengerjakan satu konten latihan hingga selesai

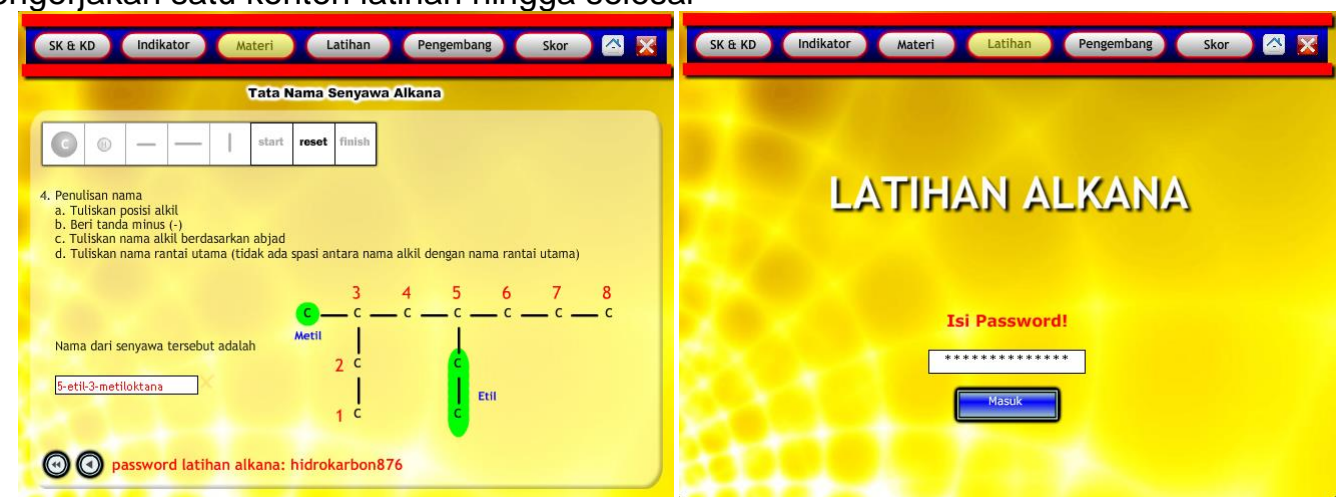

4. Pada konten materi (alkana, alkena, alkuna) siswa diminta untuk merangkai senyawa hidrokarbon. Sebelum siswa melakukan kegiatan tersebut, courseware menyediakan video tutorial mengenai cara pengerjaan dan video tersebut dapat diulang sebanyak tiga kali

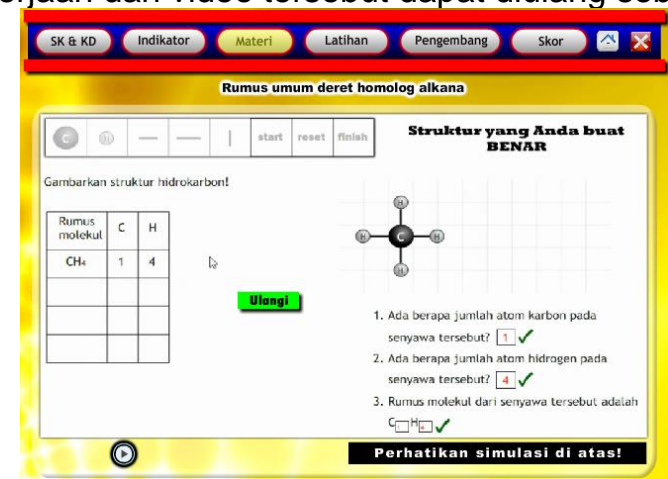

5. Pada saat kegiatan merangkai senyawa hidrokarbon pada konsep (alkana, alkena, alkuna), siswa dapat merangkai senyawa hidrokarbon secara acak. Misal siswa dapat merangkai senyawa hidrokarbon dimulai dari jumlah atom $\mathrm{C}$ sebanyak tiga, kemudian merangkai senyawa hidrokarbon dengan jumlah atom $\mathrm{C}$ sebanyak dua dst.

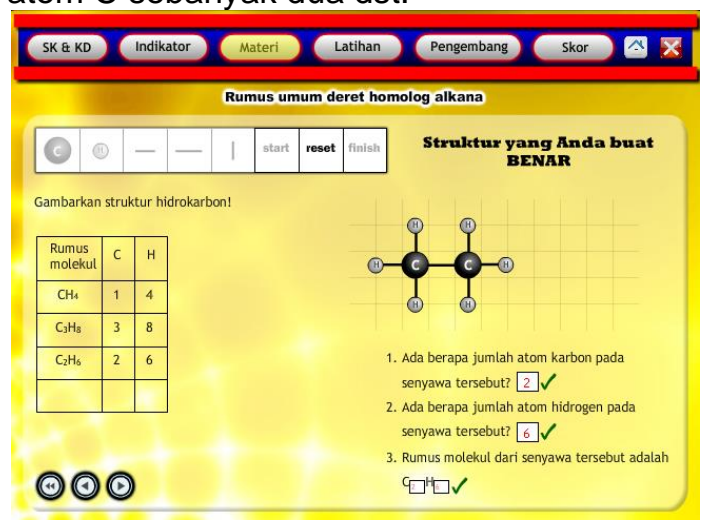


6. Pertanyaan-pertanyaan yang terdapat pada setiap konten materi mengarahkan siswa untuk berpikir inquary. Sehingga siswa dapat menemukan konsep sendiri melalui pengamatan dan pemahamannya

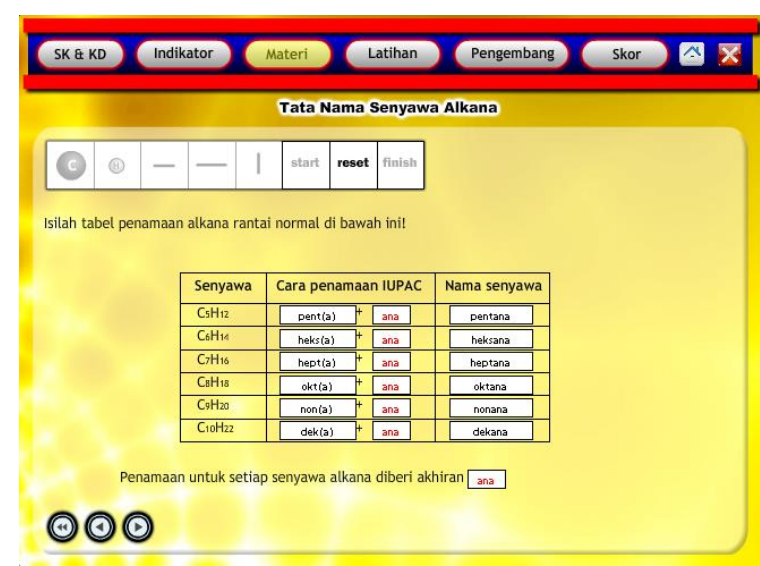

7. Courseware menyediakan beberapa kemungkinan cara dalam pemberian nama senyawa hidrokarbon (alkana, alkena dan alkuna). Sebelum siswa memulai mempelajari langkahlangkah pemberian nama tersebut. Siswa dapat mengamati video tutorial cara menentukan rantai utama dan memberi nomor pada rantai utama

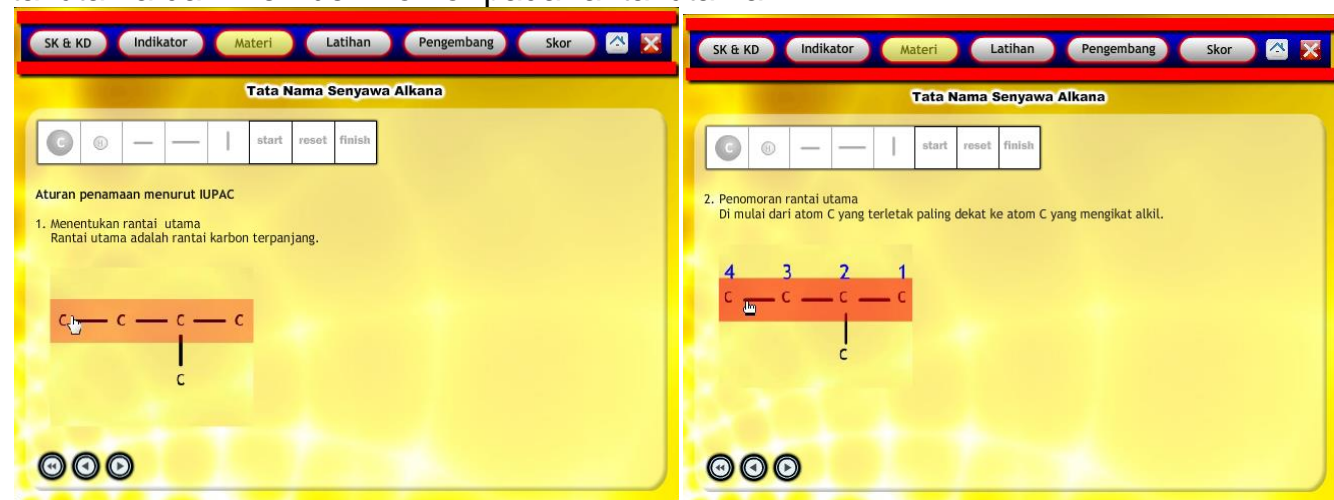

8. Courseware melakukan umpan balik secara cepat terhadap setiap kegiatan yang dilakukan oleh siswa. Misal ketika siswa mengerjakan latihan alkana dan siswa menjawab salah, siswa dapat mengklik tulisan "pelajari kembali di sini". Kemudian siswa akan di arahkan untuk mempelajari konsep yang berhubungan dengan pertanyaan tersebut. Apabila siswa sudah paham, siswa dapat mengklik tulisan "kembali ke latihan" dan siswa dapat melanjutkan untuk menjawab pertanyaan sebelumnya

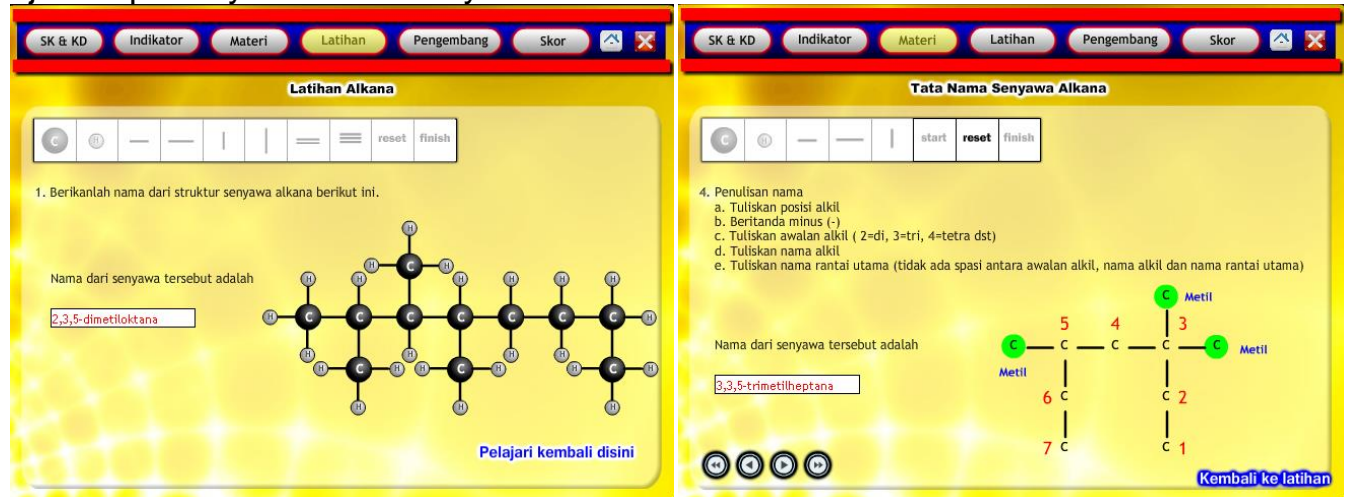

9. Courseware memiliki fasilitas untuk mengulang, sehingga apabila siswa ingin mempelajari materi tersebut dari awal siswa bisa mengulanginya, selama siswa tidak menekan tanda keluar dari courseware.

Kekurangan dari courseware:

1. Courseware tidak memiliki kemampuan untuk menyimpan data

2. Pada saat mulai menjalankan courseware, sistem memerlukan beberapa detik untuk memunculkan kolom password dan mengijinkan siswa untuk memulai pembelajaran. Ini dikarenakan sumber data berpusat di halaman awal courseware 


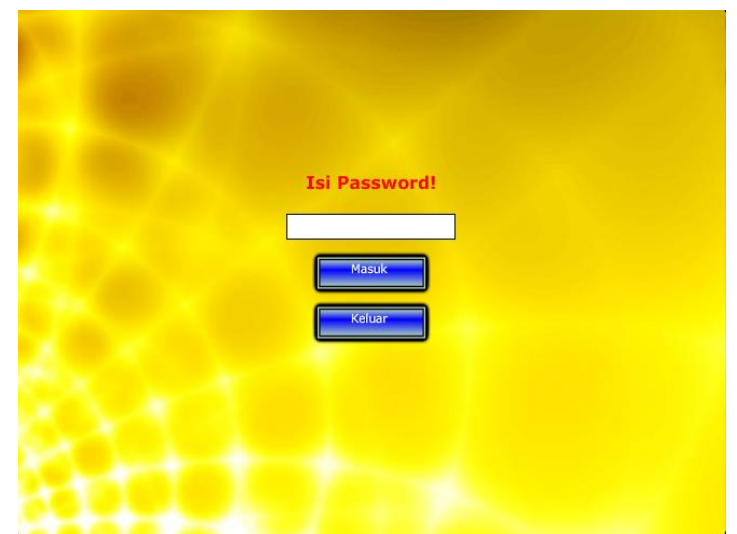

3. Pada saat siswa merangkai senyawa hidrokarbon, siswa harus menggerakkan kursor tepat pada pilihan icon-icon yang terdapat di menu. Jika tidak icon-icon tersebut tidak dapat dikeluarkan dari menu, sehingga kegiatan ini cukup memakan waktu

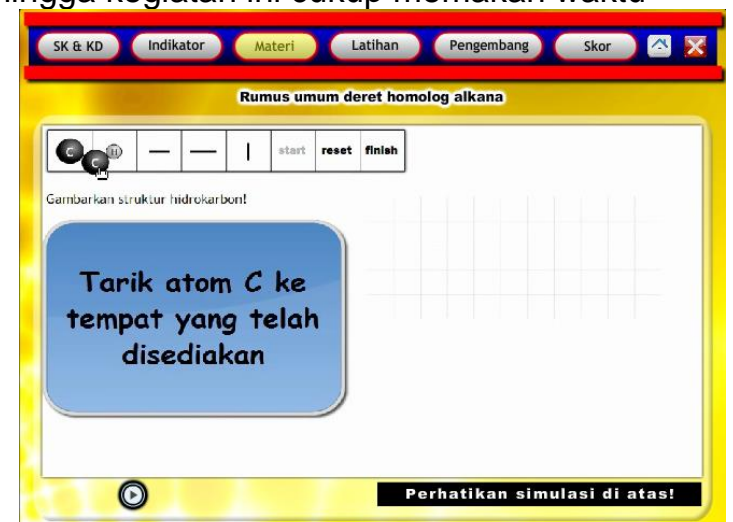

4. Pada saat siswa merangkai senyawa hidrokarbon, atom $\mathrm{C}$, atom $\mathrm{H}$, garis penghubung antara atom $\mathrm{C}$ dengan $\mathrm{C}$, dan garis penghubung atom $\mathrm{C}$ dengan $\mathrm{H}$ harus tepat di letakkan pada tempat yang telah ditentukan oleh courseware. Seharusnya apabila garis penghubung antara atom $C$ dengan $C$ sudah berada di sekitaran atom $C$ maka garis penghubung tersebut bisa langsung terikat secara otomatis dengan atom $\mathrm{C}$ tersebut.

5. Pada setiap pertanyaan yang muncul di courseware selalu dibarengi oleh kalimat cek jawaban. Kalimat ini sudah muncul sebelum siswa menuliskan jawaban dari pertanyaan tersebut. Sehingga apabila siswa mengklik kalimat cek jawaban sebanyak tiga kali maka jawaban sebenarnya dari pertanyaan tersebut akan muncul di layar. Simbol checklist yang muncul di layar dapat dijadikan tolak ukur bagi siswa yang menjawab pertanyaan dengan cara mengetikan jawaban secara benar bukan dengan cara mengklik kalimat cek jawaban sebanyak tiga kali

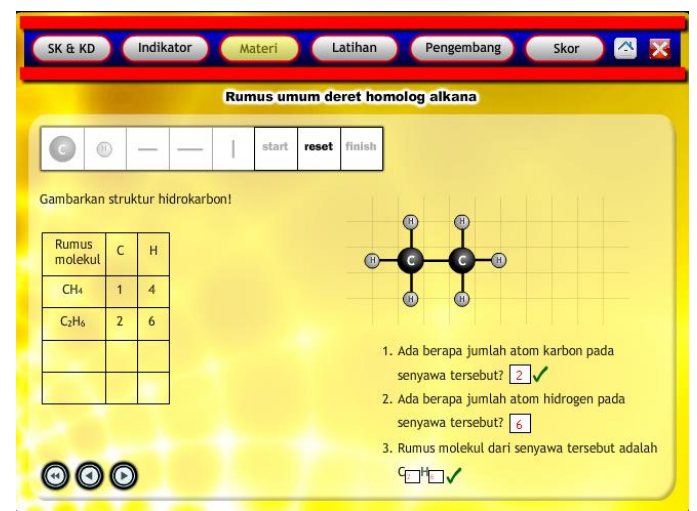

Berdasarkan data mengenai beberapa kelebihanyang dimiliki oleh courseware, maka jelas courseware ini dapat mengatasi kekurangan yang dimiliki oleh courseware yang pernah ada sebelumnya dari sisi keinteraktifan. Courseware ini dirancang agar siswa bisa menemukan konsep sendiri melalui serangkaian proses yang harus dilalui dengan diarahkan oleh beberapa pertanyaan yang selalu ada di setiap sub pokok bahasan. Sehingga siswa bukan mempelajari kimia sebagai produk tetapi merupakan suatu proses penemuan. Hal ini sejalan dengan yang diungkapkan oleh Depdiknas (2007) yaitu IPA bukan hanya sebagai penguasaan kumpulan pengetahuan yang 
berupa fakta-fakta, konsep-konsep, atau prinsip-prinsip saja, tetapi juga merupakan suatu proses penemuan.

Dengan penggunaan courseware ini aktifitas siswa akan lebih dominan, siswa akan diminta merangkai senyawa hidrokarbon, menjawab beberapa pertanyaan yang ada di setiap sub pokok bahasan, mengamati video tutorial mengenai cara merangkai senyawa hidrokarbon, memberikan nama pada setiap senyawa hidrokarbon dan menyimpulkan berdasarkan data yang ada. Dengan banyaknya kegiatan yang dilakukan, siswa tidak akan merasa bosan. Selain itu courseware dikemas secara menarik dan dapat merespon secara cepatterhadap setiap jawaban siswa. Dengan dominannya kegiatan yang dilakukan oleh siswa selama proses pembelajaran, maka siswa akan lebih mudah mengingat, memahami dan pemahaman terhadap konsep tersebut akan bertahan lama dalam pikiran siswa.

Konsep-konsep yang terdapat pada courseware ditampilkan secara bertahap berdasarkan hierarki konsep. Siswa akan mulai belajar dari konsep yang sederhana menuju konsep yang kompleks, sehingga pengalaman yang didapatkan oleh siswa lebih optimal.Menurut Bruner (dalam Dahar, 1989) penstrukturan pengetahuan perlu dilakukan agar didapatkan pemahaman optimal.

Dalam courseware terdapat beberapa video tutorial yang dapat membantu siswa diawal pembelajaran. Penggunaan video tutorial dirasakan perlu supaya siswa bisa mengerti apa yang harus dia lakukan padaslide-slide selanjutnya. Sehingga siswa dapat belajar mandiri tanpa dibantu oleh guru. Selain itu kecepatan penyelesaian satu sub pokok bahasan dapat ditentukan sendiri oleh siswa. Siswa yang memiliki kemampuan akademik lebih dapat menyelesaikan satu sub pokok bahasan dengan lebih cepat dibandingkan dengan siswa yang kemampuan akademiknya kurang. Hal ini secara tidak langsung akan memberikan dorongan dan motivasi kepada siswa untuk mempelajari konsep hidrokarbon terlebih dahulu sebelum materi tersebut diberikan oleh guru di dalam kelas. Sehingga siswa yang tingkat akademiknya kurang dapat menyesuaikan kecepatan penyelesaianterhadap satu sub pokok bahasan seperti siswa yang memiliki kemampuan akademik lebih. Menurut Sadiman (2008) media pembelajaran yang baik dapat menimbulkan kegairahan dalam belajar.

Courseware ini memiliki kemampuan untuk mengulang, apabila siswa merasa belum paham terhadap konsep yang telah dipelajari, memerlukan pengulangan dan penegasan maka siswa tersebut dapat mengulanginya kembali. Selain itu coursewarememiliki menu latihan, menu ini berguna untuk mengukur seberapa besar pemahaman siswa terhadap konsep yang telah dipelajarinya. Jawaban siswa terhadap setiap pertanyaan yang ditulis dalam menu latihan akan langsung diberikan skor, sehingga guru dapat mengetahui kemampuan siswanya dan siswa tersebut dapat mengetahui kemampuan dirinya.

Courseware ini juga dirancang untuk dapat mengembangkan kemampuan generik sains. Keterampilan generik sains yang penting dan perlu dikuasai dalam belajar IPA menurut Brotosiswoyo (2000) ada sembilan macam, tiga diantaranyaadalah bahasa simbolis, inferensi logis dan kerangka logika taat asas. Implementasi keterampilan generik sains dalam pembelajaran merupakan dasar membangun kemampuan keterampilan berpikir tingkat tinggi.

Selain memiliki beberapa kelebihan, coursewareini masih memiliki kekurangankekurangan. Hal ini disebabkan pengerjaan courseware menuntut teknik pembuatan yang cukup rumit, meskipun demikian perbaikan ke arah yang lebih baik sangat memungkinkan.

\section{SIPULAN DAN SARAN}

Penelitian ini menghasilkan sebuah courseware materi hidrokarbon yang mudah dipelajari dan bersifat interaktif. Sejumlah bentuk interaksi dapat dimunculkan melalui courseware seperti penyajian tutorial dan drill\&practise. Siswa dimungkinkan untuk memberikan respon, menerima umpan balik, menerima koreksi, mempunyai kesempatan untuk perbaikan dan memperoleh penguatan yang memadai.

\section{DAFTAR RUJUKAN}

Astir, I. D. (2007). Pemahaman konsep siswa pada sub pokok bahasan alkana,alkena dan alkuna menggunakan software pembelajaran. Skripsi UPI. Tidak diterbitkan

Brotosiswoyo, B.S. (2000). Hakikat Pembelajaran Fisika di Perguruan Tinggi. Jakarta: Proyek Pengembangan Universitas Terbuka Direktorat Jendral Perguruan Tinggi Departeman Pendidikan Nasional

Dahar, R.W. (1989). Teori-teori Belajar. Bandung: Erlangga

Depdiknas. (2007). Kurikulum Tingkat Satuan Pendidikan Mata Pelajaran Kimia SMA dan MA. Jakarta: Departemen Pendidikan Nasional

Harun, J dan Tasir, Z. (2003). Multimedia Dalam Pendidikan. Jakarta: PTS Publications 
Kartimi. (2003). Pengembangan Model Pembelajaran Interaktif Berbasis Komputer ntuk Bahan Kajian Partikel-partikel Materi Sebagai Wahana Pendidikan Siswa SLTP. Tesis UPI. Tidak diterbitkan

Karyadinata. (2006). Aplikasi Multimedia Interaktif Dalam Pembelajaran Matematika Sebagai Upaya Mengembangkan Kemampuan Berpikir Matematika Tingkat Tinggi Siswa SMA. Disertasi SPs UPI. Tidak diterbitkan

Kristi, A. (2008). Pembelajaran Praktikum Mandiri Berbasis Multimedia Komputer untuk Meningkatkan Keterampilan Generik Sains dan Berpikir Kritis Siswa Pada Konsep Tekanan Osmotik. Tesis UPI. Tidak diterbitkan

Liliasari, dkk. (1997). Pengembangan Model Pembelajaran Materi Subyek untuk Meningkatkan Keterampilan Berpikir Konseptual Tingkat Tinggi Mahasiswa Calon Guru IPA. Laporan Penelitian. Bandung: FPMIPA IKIP Bandung

Liliasari. (2005). Membangun Keterampilan Berpikir Manusia Indonesia melalui Pendidikan Fisika. Pidato Pengukuhan Guru Besar Tetap Dalam IImu Pendidikan IPA. Universitas Pendidikan Indonesia

Padmanaba, I. Ketut Gede, I. Made Kirna, and IB Nyoman Sudria. "PENGEMBANGAN MEDIA PEMBELAJARAN INTERAKTIF KIMIA KOLOID BERBANTUAN KOMPUTER UNTUK SISWA SMA." Jurnal Pendidikan Kimia Indonesia 2.1 (2018): 15-24.

Permana, I. (2010). Visualisasi Berbantuan Komputer untuk Meningkatkan Keterampilan Generik Sains dan Kemampuan Berpikir Kritis Siswa SMK pada Konsep Hidrokarbon. Tesis UPI. Tidak diterbitkan

Sadiman, dkk. (2008). Media Pendidikan. Jakarta: PT Raja Grafindo Persada

Setiadhy, H. (2006). Peningkatan hasil belajar kimia siswa SMA pada materi alkana dengan software pembelajaran multimedia interaktif. Skripsi UPI. Tidak diterbitkan

Subagja. (2006). Peningkatan hasil belajar kimia siswa SMA pada materi alkena dengan software pembelajaran multimedia interaktif. Skripsi UPI. Tidak diterbitkan

Tapilouw, F. S. (2007). Analisis Pembelajaran Biologi Berbasis Multimedia Interaktif Pada Berbagai Jenjang Pendidikan. Proceeding Seminar Internasional Pendidikan IPA ke-1 SPS UPI, Bandung, 27 Oktober 2007 